Open Access

\title{
Delivery and evaluation of an e-Learning framework through computer-aided analysis of learners' reflection text in a teacher development course
}

Siu-Cheung Kong

Correspondence: sckong@eduhk.hk Department of Mathematics and Information Technology, The Education University of Hong Kong, 10 Lo Ping Road, Tai Po, New Territories, Hong Kong

\begin{abstract}
This study aimed at proposing an e-Learning framework in school education. The proposed framework consisted of technology and pedagogy dimensions. The method of computer-aided analysis of learners' reflection text was used to evaluate the pedagogical delivery of the proposed framework. A study involving 33 in-service teachers in a teacher development course was conducted to investigate the effectiveness of the pedagogical delivery. The computer-aided analysis of learners' reflection text on "what is e-Learning" before and after the teaching of the course showed that learners deepened their understanding about the technology use and the importance of pedagogy in e-Learning, to consider more the component on theories/models/principles/strategies in pedagogical design and practices, emphasize more the reflection and discussion in learning and teaching activities, and also realize more the possibility of pedagogical decision-making using data collected from online learning. The questionnaire survey and focus group interview with learners also indicated that the pedagogical delivery of the e-Learning framework with the support from the computer-aided analysis of learners' reflection text coupled with hierarchical visualization of analysis results was positively perceived. The research findings contribute pioneering insights into the use of a computeraided approach for an accurate and efficient evaluation in teacher development courses on e-Learning.
\end{abstract}

Keywords: Computer-aided analysis, e-Learning framework, Evaluation, Reflection text, School education, Teacher development

\section{Implications for practice or policy}

- An e-Learning framework in school education was proposed. The approach of computer-aided analysis of learners' reflection text coupled with hierarchical visualization of analysis results helped deliver the framework in a teacher development course on e-Learning.

(c) The Author(s). 2021 Open Access This article is licensed under a Creative Commons Attribution 4.0 International License, which permits use, sharing, adaptation, distribution and reproduction in any medium or format, as long as you give appropriate credit to the original author(s) and the source, provide a link to the Creative Commons licence, and indicate if changes were made. The images or other third party material in this article are included in the article's Creative Commons licence, unless indicated otherwise in a credit line to the material. If material is not included in the article's Creative Commons licence and your intended use is not permitted by statutory regulation or exceeds the permitted use, you will need to obtain permission directly from the copyright holder. To view a copy of this licence, visit http://creativecommons.org/licenses/by/4.0/. 
- Teachers' pre-post-course reflections showed a growth of e-Learning understanding with the support of the e-Learning framework and learners realized more the importance of pedagogy in e-Learning.

\section{Introduction}

The goal of e-Learning in school education in the coming 10 years is to foster the development of 21st century skills among learners (Kong et al., 2014; Koh et al., 2017). Teachers in school education need guidance of how to promote e-Learning for developing learners' 21st century skills. This demands teacher development for empowering in-service teachers to truly understand the core concepts of e-Learning to plan and implement concept-driven e-Learning strategies for learners in the 21st century. An eLearning framework which addresses both the aspects of technology and pedagogy in defining what is e-Learning is desired. For better preparing teachers to realize such eLearning framework, the corresponding teacher development course should be designed to address the gaps between teachers' actual understanding of e-Learning and the desirable framework of e-Learning. The approach of computer-aided analysis of learners' reflection text which bases on the desirable e-Learning framework can help analyze teachers' understanding and facilitate its pedagogical delivery in teacher development course. This study made a pioneering effort to propose an e-Learning framework for the delivery and evaluation through computer-aided analysis of learners' reflection text in the teacher development course on e-Learning in school education.

\section{Background of the study}

In this study, e-Learning is defined as a process of implementing pedagogy with the support of digital technology for achieving educational goals (Kong \& Song, 2014, 2015). This definition is formulated with the consideration of more and more integration of e-resources, digital communication processes, and use of digital data for learning support in e-Learning context throughout recent decades. From late 1990s to the mid of 2000s, the Internet was popularized around the world and its use was penetrated in every aspect of daily life, including education (Krasnova et al., 2017; McConnell, 2018). The tremendous digital resources available on the Internet widened the choices of resource deployment for teaching, besides the use of traditional textbooks (Krasnova et al., 2017; Leow et al., 2016). With the technological advancement of computing devices as well as software tools and apps since early 2000s, there was an increasing trend of integrating these digital resources into classroom learning and teaching (Leow et al., 2016; Zanjani et al., 2017). The school education at this stage focused e-Learning development on the technological aspect, paying attention to the selection and use of different types of computing devices and digital resources for learning and teaching purposes.

Building on the emphasis of technological integration into learning and teaching for years, practitioners realized the need of more pedagogical considerations for advancing towards quality e-Learning. Since the mid of 2000s, there has been more advocacy of promoting learners to learn with diverse digital resources that encourage active engagement in constructive learning and peer interaction for developing subject knowledge (Blundell et al., 2020; Damnik et al., 2017). This drove an additional emphasis on the pedagogical rationales of e-Learning in school education. In the recent decade, more 
attention has been paid to pedagogy in e-Learning context for the development of 21st century skills. The realization of this educational goal needs a process of active, constructive, and interactive learning for learners to develop and apply skills such as inquiry, critical thinking, communication, and collaboration in the 21st century (Kong et al., 2014; Chou et al., 2019; Rodríguez et al., 2017). The theoretical perspective of constructivist learning is considered favorable to the design and deployment of effective pedagogy for e-Learning (Mchaney et al., 2018; McKnight et al., 2016). The creation of e-Learning environments which implement a constructivist learning approach has placed an additional opportunity for learners to progressively deepen subject knowledge through a convenient access to appropriate resources and sharing of useful information among learning peers (Blundell et al., 2020; Kong et al., 2014). Similar pedagogical guides such as the promotion of models like inquiry-based learning (Acar \& Tuncdogan, 2019; Kong \& Song, 2014), principles like learner-centered learning (Kong et al., 2014; Walt \& Barker, 2020), and strategies like flipped classroom activity design (Blair et al., 2016; Blau \& Shamir-Inbal, 2017) for engaging learners in preparation, learning process, and reflection are advocated.

With this driving force of pedagogical guidance, the additional opportunity of eLearning in school education is the promotion of online interactions among peers from the constructivist perspectives for knowledge construction. This creates the pedagogical need of digital communication among learners in e-Learning environments. Learners in e-Learning process are often required to use digital communication ways to interact and collaborate with peers to complete learning tasks and share learning outcomes (Rodríguez et al., 2017; Varier et al., 2017). On the one hand, there is an increasing trend of using discussion forums in learning management systems (LMSs) for online discussions and peer assessment in formal learning context. The online interaction features of LMSs enable learners to share learning-related information and resources from multiple sources and support their construction and reflection on subject knowledge in the learning process (Kong, 2015; Zanjani et al., 2017). On the other hand, there is an increasing use of social networking systems for online sharing in non-formal learning context. One of the educational use of social networking systems is sharing bookmarks which can be used for the breakthrough of the traditional mindset and the consideration of alternative viewpoints in online sharing (Eid \& Al-Jabri, 2016; Greenhow \& Lewin, 2016).

Another emerging opportunity is the pedagogical use of online data generated from digital platforms. Such a digital way of collecting data facilitates convenient ways of recording, analyzing, and providing timely feedback to learners' learning process and learning outcomes. The tools such as discussion forums used in digital platforms store extensive data of learning of learners and records of interactions among peers in the learning process. These data provide opportunities for teachers and researchers to conduct learning analytics for analyzing data generated from these e-Learning environments. The analyzed data provide evidence of the learning progress, no matter it is effective or not (DiCerbo, 2020; Kong et al., 2014). Teachers therefore can use such evidences to make pedagogical decisions to support learners' learning in an informed manner. On the one hand, learners can accumulate learner-centered learning experience and create learner-centered learning portfolio using these learning data. On the other hand, teachers can provide timely feedback and support according to learners' learning performance in the learning process (Littlejohn et al., 2016; Yen et al., 2018). 
The developmental trends of e-Learning in the recent decades have emphasized the importance of pedagogy for active, constructive, and interactive learning. These trends drive teacher development on e-Learning in the 21st century to put more emphasis on preparing in-service teachers to transform their pedagogical beliefs and practices through technological integration, of which the quality of learning and teaching is expected to be enhanced by an effective application of digital resources, digital communication, and digital assessment (Albion et al., 2015; Kong et al., 2014; Liao et al., 2017).

Opportunities for self-reflection and peer-sharing are considered essential in such teacher development, in which teacher participants articulate their changes in the pedagogical belief and knowledge of technological integration into curriculum delivery (Jones \& Dexter, 2018; Koh et al., 2017; Yurtseven Avci et al., 2020). One of the best ways is to arrange teacher participants to write reflection text iteratively in different time points of teacher development courses for engaging them in the self-reflection opportunities (Bashan et al., 2017; McLean \& Price, 2019). The writing of reflection text is considered effective to encourage teacher participants to reflect on their changes achieved in teacher development courses (Bashan et al., 2017; McLean \& Price, 2019). The provision of scaffolding for such writing is further considered helpful to support teacher participants to retrieve, familiarize and connect the fundamental concepts in the learning topics (Bashan et al., 2017; Pereira et al., 2016). The reflection text generated by the teacher participants is recognized as promising to be both treatment and measurement of teacher development. Such reflection text is, on the one hand, a learning process that engages teacher participants in developing the target knowledge and pedagogy, and on the other hand, a learning product that records teacher participants' changes in developing the target knowledge and pedagogy (Bashan et al., 2017; McLean \& Price, 2019).

Although the existing teacher development on e-Learning generally includes a reflective approach to support teachers' professional learning, there is no final conclusion on an accurate and efficient evaluation of teachers' self-reflection products for a critical analysis of their growth in professional knowledge about e-Learning (Albion et al., 2015; Liao et al., 2017; Tondeur et al., 2016). In recent years, the approach of learning analytics with results-presentation in visual-form is advocated to be a computer-aided approach feasible to be both treatment and measurement of teacher development in a more efficient and less tedious manner (Fahrenbach et al., 2019; McKenna et al., 2019). The process of this approach is receiving a documentation of learner learning (such as a set of learner-generated reflection text) and a dictionary of professional competency (such as a topic-specific keyword framework which serves as a reference point for the evaluation) and then returning a match between them (Fahrenbach et al., 2019; Noroozi et al., 2019). This computer-aided approach commonly uses LMS learning analytics to create visual representations of online data for two main purposes: as a feedbackprovision for learners to deepen their topic-specific understanding; and as a scaffolding-support for learners to reflect on their topic-specific learning (McKenna et al., 2019; Vieira et al., 2018).

Researchers such as Bikakis et al. (2017) and Elmqvist and Fekete (2010) recommend the use of hierarchical visualization tools in such learning analytics context to make the visual representations more visually scalable and less cluttered. Hierarchical visualization tools allow teachers and learners to visually explore large sets of data in a 
multilevel manner, as those tools afford an intuitive and practical way for teachers and learners to look at the overview of a dataset as well as look into specific parts within a dataset. Elmqvist and Fekete (2010) and Vieira et al. (2018) denote that the application of hierarchical visualization in learning analytics commonly involves the techniques for visualizing the structure and summary of the multilevel representations of learning data (such as the count and sum of certain items in the data collected from students' contributions to course discussion forums online on LMS), and interacting with the multiscale data-display through visual exploration operations (such as zooming in-and-out and drilling up-and-down of bubble plots in the data-display for moving across the different levels in the hierarchy to show more or less of the data details).

Accordingly, this study developed an e-Learning framework to guide in-service teachers in school education to understand e-Learning for fostering knowledge construction; as well as delivered and evaluated it through computer-aided analysis of learners' reflection text coupled with hierarchical visualization of analysis results in a teacher development course on e-Learning for exposing in-service teachers to a theoretically-guided and evidence-based e-Learning process for knowledge construction, learning interaction, and pedagogical decision-making. This study focused on two research questions: (1) What should be the e-Learning framework for the delivery through computer-aided analysis of learners' reflection text in the teacher development course on e-Learning in school education? (2) How will be the evaluation of learners' learning through computer-aided analysis of learners' reflection text in the teacher development course using the proposed e-Learning framework?

\section{Development of an e-Learning framework of the study}

In response to the first research question, this study developed an e-Learning framework to support school education for realizing the educational goal in the 21st century. The design of the proposed e-Learning framework also referred to related e-Learning frameworks. Oktavia et al. (2016) review that the two most concerned elements in eLearning frameworks since 2000 are content and pedagogy. Aparicio et al. (2016) present an e-Learning framework which concerns three elements: the people, the technology, and the services. Pedagogical models and instructional strategies are discussed in the services. Adekola and Dale (2017) present an e-Learning framework which concerns six elements: physical infrastructure, learning technology support, pedagogy, management and organization, institutional culture, and ethical/legal. The common elements in these frameworks are technology and pedagogy in e-Learning. The proposed e-Learning framework in this study was therefore designed to have two dimensions: technology and pedagogy (see Fig. 1). Referring to the discussion in the background of this study, the technology dimension in the proposed framework composes of three components. They are the use of e-resources, digital ways of communication, and digital ways of collecting data in the e-Learning process. The pedagogy dimension concerns theories/models/principles/strategies in guiding the design of learning and teaching activities as well as the use of data collected to provide evidence-based pedagogical decision-making/supports in the e-Learning process.

In Hong Kong, English and Chinese are the two languages commonly used in the process of learning and teaching. To capture the understanding of e-Learning of teachers in Hong Kong, a set of bilingual keywords in English and Chinese was derived 


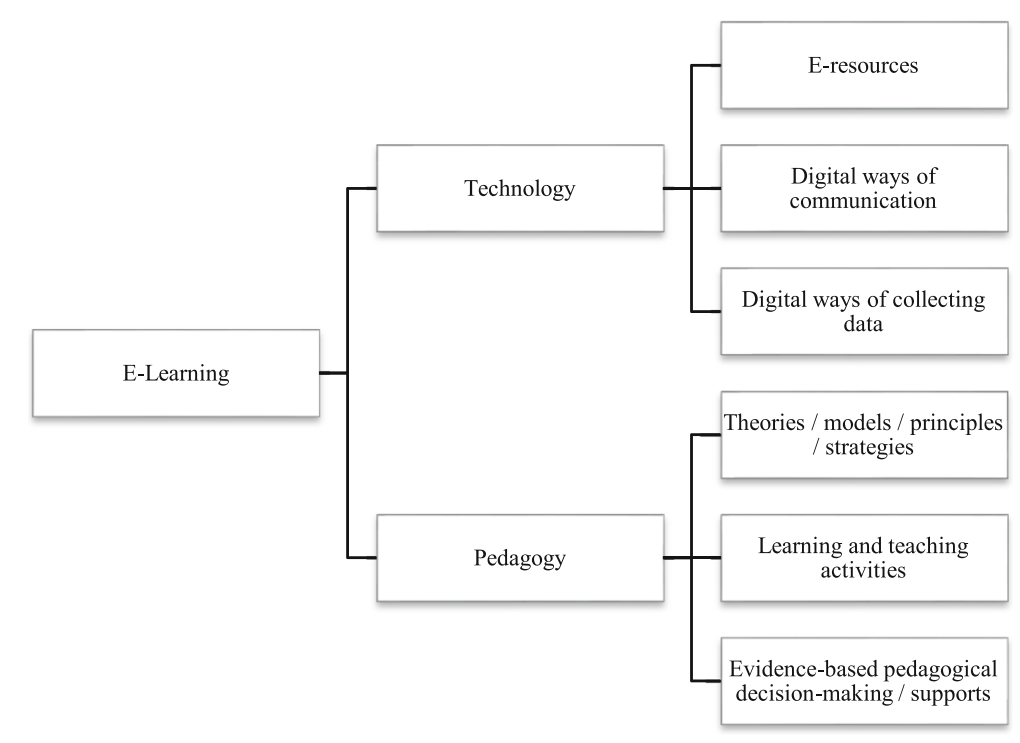

Fig. 1 An e-Learning framework in school education consisting of two dimensions and six components

for each of the six components across the two dimensions in the proposed e-Learning framework. Three approaches were adopted for deriving the sets of bilingual keywords of the proposed e-Learning framework. Firstly, based on the current research and practices of e-Learning, the teacher responsible for the teacher development course in this study designed the keywords including synonyms in both English and Chinese. Secondly, based on learners' reflection of the teacher development course, a manual search of additional relevant words in learners' reflection text was conducted to enrich the bilingual keyword sets. Thirdly, the enriched sets of bilingual keywords were further checked with Google Translate for validating the connection between the English and Chinese versions of each keyword.

The keywords of the technology dimension in e-Learning related to the use of eresources, digital ways of communication, and digital ways of collecting data are summarized in Table 1. The categorization of the keywords related to the use of eresources in school education is grouped into four categories according to their ways of use in school education. E-textbook is a category in which school curriculum eresources are putting up together in a structural manner for convenient access and use across a substantial curriculum delivery period. Curriculum-related e-resources are another category and typically are topic-wise e-resources purposely designed for use as part of the school curriculum. Open courseware is a category that may or may not relate to the school curriculum and it is in general for self-paced or self-regulated learning. The fourth category is e-resources in general that are available for learners' and teachers' consideration of use as resources in learning and teaching activities which are not purposely designed for school use. The second component is digital ways of communication. Currently, it is grouped into four categories. One category is the classroom use of digital communication tools for engaging learners and enhancing interactions in classrooms. Another category is the use of digital platforms for engaging learners and extending interactions among learners which happen in general outside classrooms. The third category is interactions of learners and teachers in social networks. The 
Table 1 Finalized keywords of this study on the technology dimension of the proposed eLearning framework

\begin{tabular}{|c|c|}
\hline $\begin{array}{l}\text { Technology-based } \\
\text { components }\end{array}$ & Keywords \\
\hline E-resources & 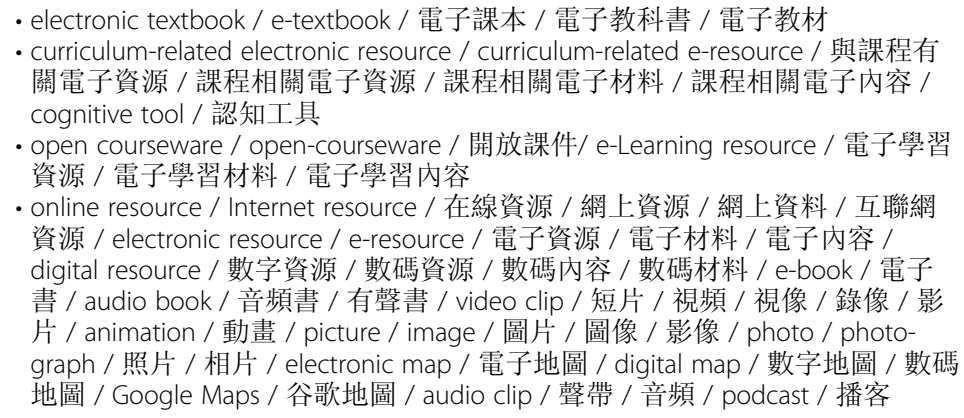 \\
\hline $\begin{array}{l}\text { Digital ways of } \\
\text { communication }\end{array}$ & $\begin{array}{l}\text { • classroom communication / 教室交流 / 課堂交流 / 教室溝通 / 課堂溝通 / } \\
\text { BYOD } \\
\text { - discussion forum / forum / 論壇 / 討論區 / learning management system / 學習 } \\
\text { 管理系統 / Moodle / Edmodo / Schoology / Blackboard / Mahara / Fronter / } \\
\text { Google classroom / 谷歌教室 / e-Learning platform / 電子學習平台 / 電子平台 } \\
\text { / platform / 平台 } \\
\text { • social network / 社交網絡 / Facebook / 面書 / 臉書 / Twitter / 推特 / WhatsApp } \\
\text { / WeChat / 微信 / Line / Skype / MSN / email / 電子郵件 / 電郵 / 郵件 } \\
\text { • blog / 博客 / web page / webpage / 網頁 / SMS / 短信 }\end{array}$ \\
\hline $\begin{array}{l}\text { Digital ways of collecting } \\
\text { data }\end{array}$ & $\begin{array}{l}\text { - formative data / 形成數據 / 形成性數據 / 進展性數據 / formative assessment / } \\
\text { 進展性評估 / 形成性評估 / quiz / 測 / test / 測試 / 測驗 / project / 專題 / 項 } \\
\text { 目 / survey / 調查 / questionnaire / 問券 / text / 文本 / e-portfolio / eportfolio / } \\
\text { 電子學習歷程檔案 / 個人學習歷程檔案 / instant data / 即時數據 / Nearpod / } \\
\text { record / 記錄 / count / 數數 / statistics / 統計 / note-taking / 做筆記 / photo- } \\
\text { taking / picture-taking / 拍照 / 影相 / video-taking / 拍片 / 視頻拍攝 / 錄像拍攝 } \\
\text { / search / 搜索 / 搜尋 / 尋找 } \\
\text { - summative data / 總結性數據 / summative / 數據收集 / collect data } \\
\text { examination / exam / 考試 / data collection / 數集數據 }\end{array}$ \\
\hline Digital technology & 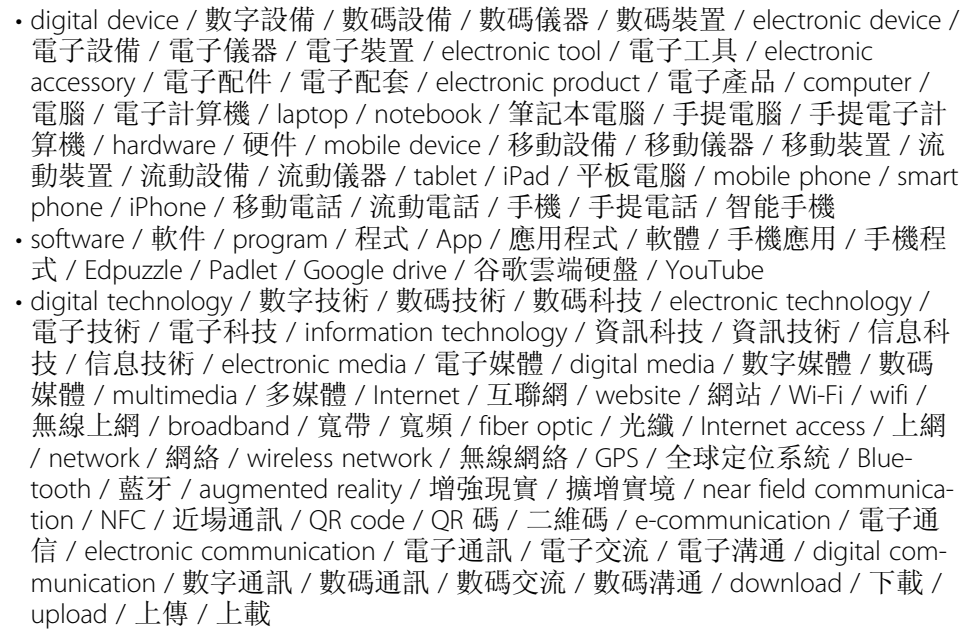 \\
\hline
\end{tabular}

fourth category enables learners to share their expression/views/reflection other than the above categories. The third component is digital ways of collecting data. It covers formative and summative types of data collection. Formative data are data collected during the learning process such as text from the discussion forum. Summative data are data collected at the critical point of a learning process that learning outcomes need to be evaluated and reported. 
It should be noted that an additional component of digital technology was added to the technology dimension of the proposed e-Learning framework to cover technological items, such as hardware devices, software products, and general digital technology, which are commonly found in e-Learning environments but not closely coupled with goals of learning and teaching activities. This additional component was added for analyzing the reflection text produced by learners at the beginning and the end of the course. In general, learners of the teacher development course produce more proportion of keywords of this type at the beginning of the course and less towards the end of the course after a more thorough understanding of e-Learning in school education. Table 1 shows the finalized list of bilingual keywords regarding the technology dimension of the proposed e-Learning framework.

The keywords in the pedagogy dimension concerns learning and teaching activities guided by theories/models/principles/strategies in pedagogical design and practices as well as the use of digital learning data to support pedagogical decision-making. This dimension involves three components. The first component is theories/models/principles/strategies-mainly addressing the epistemic rationales favorable to e-Learning, such as constructivist theories guiding the learning process; models for inquiry-based learning; principles facilitating learner-centered learning; and strategies like flipped classroom design for engaging learners in the learning process. The second component is learning and teaching activities-mainly concerning the tasks in e-Learning environments for learners to make reflection for knowledge construction; to interact with peers and teachers for resource sharing and idea exchange; to receive feedback for learning improvement and to obtain scaffolding support for guiding their learning process. The third component is evidence-based pedagogical decision-making/supports-mainly addressing learning data collection in the learning process, analyzing data collected from learners, and finally, revising or modifying ways of teaching with evidence from learning analytics.

The proposed e-Learning framework has the primary rationale that the use of technology in learning and teaching activities in the e-Learning context should be driven by the pedagogical theories/models/principles/strategies selected by teachers. For example, teachers who select the constructivist theories for e-Learning implementation need to base on their selected theories to design learning and teaching activities for e-Learning lessons, which involve the use of e-resources, digital ways of communications as well as digital ways of collecting data for promoting knowledge construction and evidencebased pedagogical decision-making. Table 2 shows the finalized list of bilingual keywords regarding the pedagogy dimensions of the proposed e-Learning framework. The finalized bilingual keyword sets were used in the course as the basis for interpreting learners' understanding of e-Learning in their reflection on e-Learning understanding before and after the course, of which learners could write their reflection text in English, Chinese, or a mixture of English and Chinese.

\section{Delivering the e-Learning framework and investigating the effectiveness}

In response to the second research question, this study delivered the proposed eLearning framework to a cohort of in-service teachers. The methods of computer-aided analysis of learners' reflection text (bilingual in English and Chinese), questionnaire survey, and focus group interview were used to investigate the effectiveness of the 
Table 2 Finalized keywords of this study on the pedagogy dimension of the proposed e-Learning framework

\begin{tabular}{|c|c|}
\hline $\begin{array}{l}\text { Pedagogy-based } \\
\text { components }\end{array}$ & Keywords \\
\hline $\begin{array}{l}\text { Theories/models/principles/ } \\
\text { strategies }\end{array}$ & 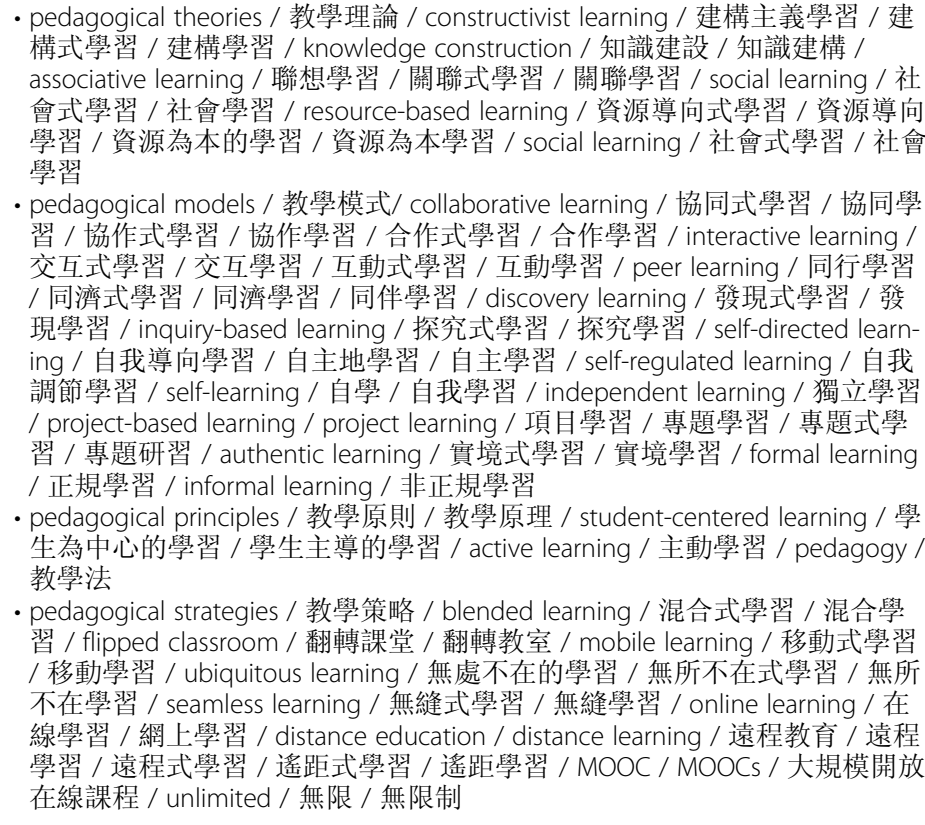 \\
\hline $\begin{array}{l}\text { Learning and teaching } \\
\text { activities }\end{array}$ & $\begin{array}{l}\text { - reflection / 反思 / review / 評論 / 檢討 / inquiry / 探究 } \\
\text { - discussion / 討論 / communication / 通訊 / 交流 / 溝通 / collaboration / 協作 } \\
\text { / 合作 / sharing / 分享 / interaction / interactive / 互動 / activities / 活動 } \\
\text { - feedback / 反饋 / 回饋 / real-time feedback / 實時反饋 / 實時回饋 / instant } \\
\text { feedback / 即時反饋 / 即時回饋 / real-time / real time / 即時 / 實時 / inter- } \\
\text { vention / 介入 / response / 回應 } \\
\text { - scaffolding / 鷹架 / 腳手架 / learning support / 學習支持 / 學習支援 }\end{array}$ \\
\hline $\begin{array}{l}\text { Pedagogical decision- } \\
\text { making/supports }\end{array}$ & 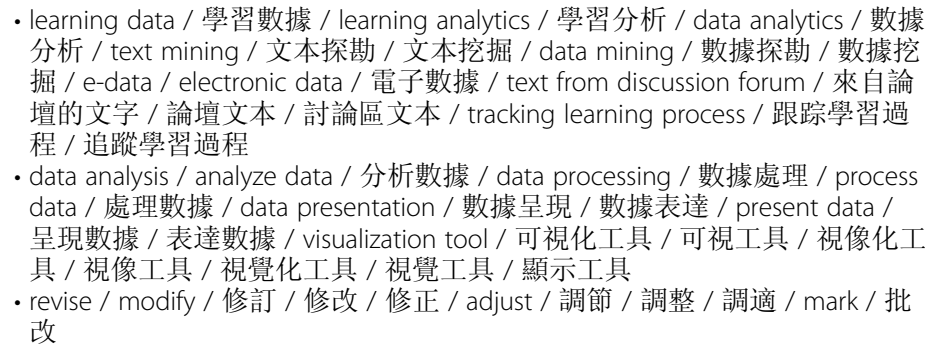 \\
\hline
\end{tabular}

pedagogical delivery of the proposed e-Learning framework for enhancing learners' understanding of e-Learning in school education.

\section{Design of the teacher development course for pedagogical delivery Course participants}

The proposed e-Learning framework was delivered to a cohort of 33 (14 male and 19 female) in-service primary school teachers in a course "E-Learning in Primary Schools" in a university in Hong Kong. The participants had an average teaching experience of 16 years ( $\mathrm{SD}=6.355$ years). Most of the participants taught the subjects Information Technology and Mathematics, while the others taught the subjects Chinese, English, and General Studies. The sample size with 33 participants is justified to be adequate 
for the high-power statistical tests in the evaluation part in this study, with $\alpha=0.05$ and power $=0.8$.

\section{Course delivery and features}

The teacher development course consisted of seven 3-h lessons for the pedagogical delivery of the proposed e-Learning framework (see Table 3). The course covered both

Table 3 Pedagogical design and practices of the seven lessons of the teacher development course

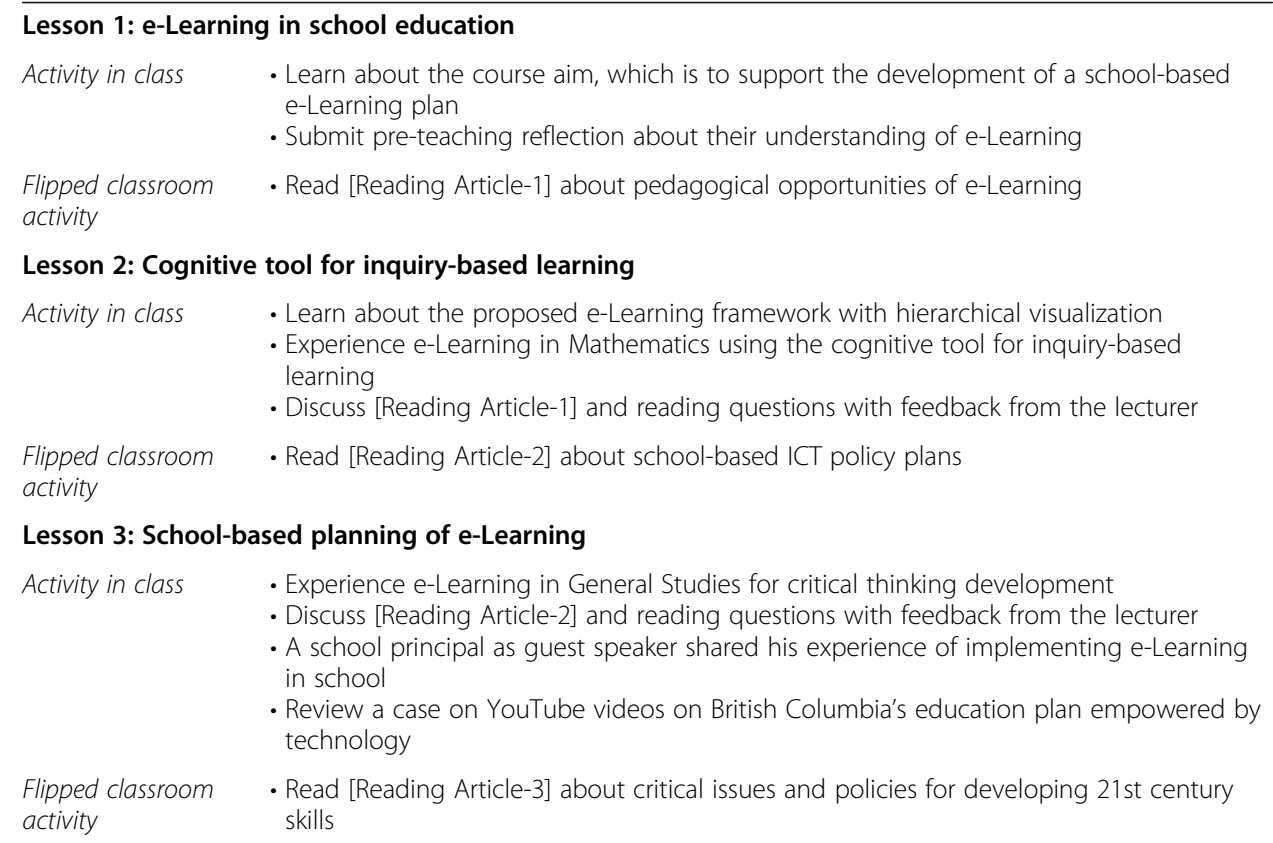

\section{Lesson 4: Deep learning and 21 st century skills}

$\begin{array}{ll}\text { Activity in class } & \text { - Experience e-Learning in Chinese for the deep learning of the subject matter } \\ & \text { - Discuss [Reading Article-3] and reading questions with feedback from the lecturer } \\ & \text { - In-class response for dissemination and diffusion theory } \\ & \text { - Visit a digital classroom in a school } \\ \text { Flipped classroom } & \text { - Read [Reading Article-4] about dissemination and diffusion theory } \\ \text { activity } & \end{array}$

\section{Lesson 5: Mobile technology supported classroom}

Activity in class - Experience e-Learning in English among learning peers

- Discuss [Reading Article-4] and reading questions with feedback from the lecturer

- Peer learning activity on mobile applications and peer review

- Discuss bridging the gap between technology and education

- A guest speaker to talk about connectivity in the digital classroom

Flipped classroom - Read [Reading Article-5] about bridging the gap between technology trends and the activity use of technology in schools

\section{Lesson 6: Digital resources in e-Learning \\ Activity in class $\quad$ Discuss the use of digital resources in the e-Learning process together with digital ways of communication among learning peers and information literacy \\ - Discuss [Reading Article-5] and reading questions with feedback from the lecturer \\ Activity outside class - Submit post-teaching reflection about their understanding of e-Learning}

\section{Lesson 7: Group presentation on e-Learning plan}

Activity in class $\quad$ Group proposal presentation on an e-Learning plan of a school

- Discussion with lecturer and peers 
theoretical knowledge introduction and hands-on experiences for learners to understand the opportunities and challenges of implementing e-Learning across major subjects in primary schools. The course is targeted at fostering learners to realize the importance of pedagogy in e-Learning. It was expected that after completing the course, learners could have the knowledge to design e-Learning plans for their schools and develop pedagogical practices for e-Learning deployment in major subjects in primary schools. The course delivery was designed with five features for realizing its educational goals.

First, the course emphasized reflection opportunities for learners in course learning. The learners were asked to submit an online reflection on their understanding of eLearning in the first lesson, as the pre-teaching reflection before the pedagogical delivery of the proposed e-Learning framework. After the sixth lesson, learners were asked to submit their second online reflection, as the post-teaching reflection. This feature enabled teachers to experience the meaning of evidence-based pedagogical decisionmaking in guiding learners to understand e-Learning in school education if gaps are identified from the pre-teaching reflection with the proposed framework.

Second, the course started to introduce the proposed e-Learning framework in the second lesson through reporting learners' pre-teaching reflection. Between the second and fifth lessons, the lecturer repeatedly arranged the learners to interact with the hierarchical visualization of the results on computer-aided analysis of their pre-reflection in the individual-student and whole-class manner. The learners had many opportunities to access the topic-specific keywords at the overall (i.e., "pedagogy vs technology"), dimension-specific (e.g., "pedagogy" only), and component-specific (e.g., "pedagogical decision-making/supports" only under the "pedagogy" dimension) levels when they browsed and clicked on the different layers in such hierarchical visualization (see Fig. 2 for an example). With the belief that technological integration in e-Learning environments should be guided by a theoretical framework, related issues in the pedagogy dimension of e-Learning such as theories of constructivist learning for developing 21st century skills, models of inquiry-based learning, principles of learner-centered learning, and evidence-based pedagogical decisions were discussed; apart from the issues of the technology dimension of e-Learning such as e-resources, digital ways of communication and digital ways of collecting data. This feature enabled the learners to realize the importance of pedagogy in practicing e-Learning.

Third, the course emphasized the subject-specific e-Learning experience for the learners. With the belief that teachers' first-person experience in e-Learning best convinces the benefits of e-Learning, the course arranged four 30-minute subject-specific e-Learning teaching experience sections in the second to fifth lessons. Learners in these sections experienced hands-on practice of e-Learning pedagogical examples such as inquiry-based learning for four major subjects in primary school education, namely Chinese, English, Mathematics, and General Studies. This feature enabled the learners to experience how technology and pedagogy are integrated for delivery in a subjectspecific area.

Fourth, the course adopted the flipped classroom strategy for pedagogical delivery (Kong, 2014, 2015). In this course, the teaching in the second to sixth lessons asked the learners to read selected articles before class, and then discuss the articles read for idea sharing inside class time. This feature not only enabled the teacher to better arrange 


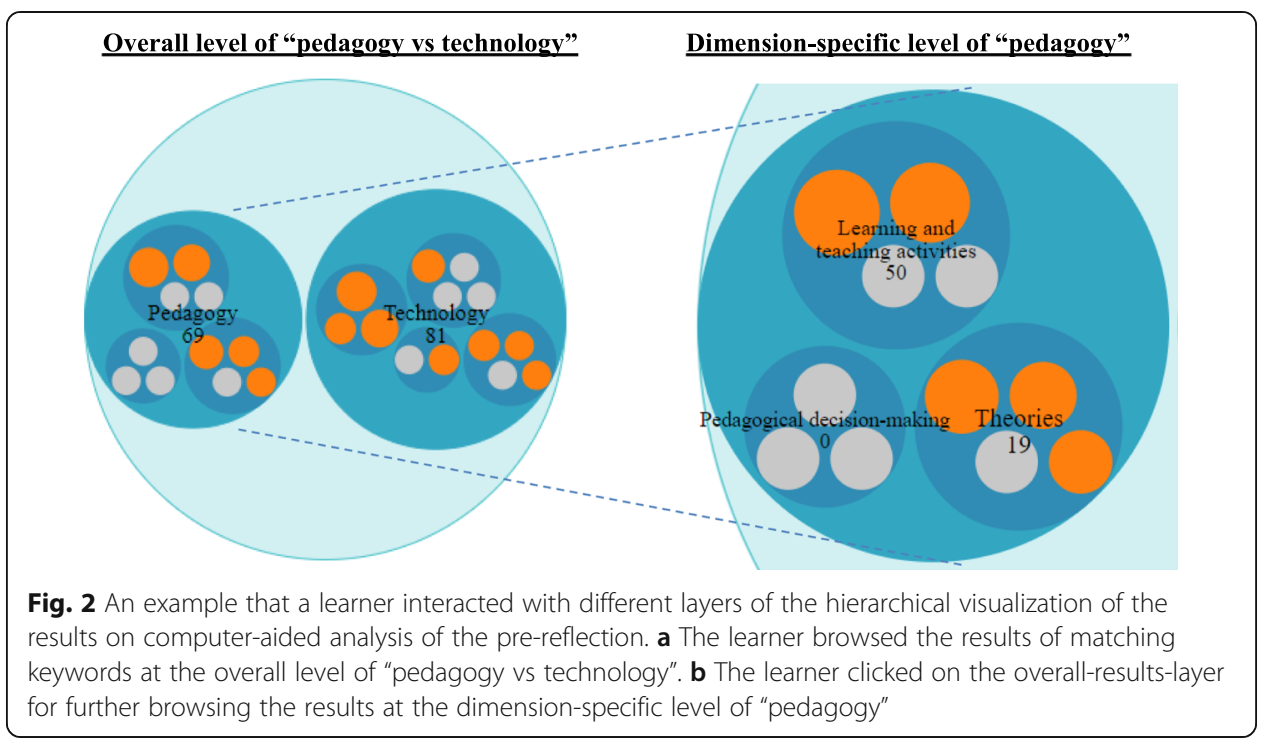

course teaching time for learner-centered learning; but also enabled the learners to experience the pedagogical strategy for e-Learning in school education.

Fifth, the course engaged learners in classroom observation for learning reflections. In the fourth lesson of the course, learners visited a classroom with students bringing along their own digital devices for observing e-Learning practice in subject-specific lessons. This feature enabled the learners to deepen their understanding of e-Learning through using the framework to guide reflection on the observed teaching practices in real classroom.

\section{Methods of investigating the effectiveness of the pedagogical delivery}

The effectiveness of the pedagogical delivery was evaluated with two focuses: (1) Can the pedagogical delivery of the proposed e-Learning framework support learners to enhance their understanding of e-Learning? (2) How do the learners perceive the helpfulness of the support from the computer-aided analysis of learners' reflection text coupled with hierarchical visualization of analysis results on promoting their e-Learning understanding? Computer-aided analysis of learners' reflection text-bilingual in English and Chinesewas used to compare learners' online reflection on their understanding of e-Learning at the beginning and towards the end of the teacher development course, namely preteaching reflection, and post-teaching reflection. A statistical power analysis was conducted for the method of computer-aided analysis of learners' reflection text. The effect size in this method was 0.756, which was considered as large according to Egberink et al. (2015). In addition, for data triangulation purposes, a questionnaire survey and a focus group interview were conducted to investigate learners' perceptions of the effectiveness of introducing the e-Learning framework with the support from the computer-aided analysis of learners' reflection text coupled with hierarchical visualization of analysis results.

\section{Analysis of learners' understanding of e-Learning by the computer-aided analysis of learners' reflection text}

Learners were asked to reflect on their understanding of e-Learning in the first and the sixth lessons of the course. The computer-aided analysis identified and counted 
learners' matching keywords used in their reflections based on the sets of bilingual keywords as shown in Tables 1 and 2 of the e-Learning framework of this study. A hierarchical visualization tool based on the proposed e-Learning framework was designed and adopted in this study for an interactive visualization of the computer-aided analysis results through web browsers. This enabled the teachers and learners of the course to visualize the computer-aided analysis results interactively according to the details of the results at various levels hierarchically on-demand. The results were represented through a ringed circular layout of nodes, in which a node and all its children were placed in a circle. This hierarchical visualization tool represented each dimension and its corresponding components of the proposed e-Learning framework as a circular layer (at the dimension level) encompassing a number of balls (at the component level). The blue color scheme of different layers got deeper according to the layering in the proposed e-Learning framework. A keyword set was denoted by an orange ball if there was at least one keyword of that keyword set mentioned by learners' reflections; otherwise, it was denoted by a gray ball. The size of an orange ball was proportional to the number of matching keywords of the corresponding keyword set. By viewing the number and size of the orange balls through this hierarchical visualization tool, teachers and learners of the course could understand the dimensions and components covered by the reflection text.

\section{Analysis of learners' perception of the support from the computer-aided analysis of learners' reflection text coupled with hierarchical visualization of analysis results by questionnaire survey}

To investigate learners' perception of the support from the computer-aided analysis of learners' reflection text coupled with hierarchical visualization of analysis results on enhancing their understanding of e-Learning, a questionnaire survey consisting of 10 question items in a 5 -Likert scale ( 1 = strongly disagree to $5=$ strongly agree) was conducted. Among the 33 learners in this study, 31 learners completed this survey for indicating how the computer-aided analysis with hierarchical visualization could support them to understand the domain-specific intellectual ideas, link personal learning intentions and expectations, and make social interactions with peers in the learning process (Kong \& Song, 2015). The Cronbach's alpha reliability coefficient of this survey was 0.900. The quantitative data collected were analyzed by SPSS software.

\section{Analysis of learners' perception of the support from the computer-aided analysis of learners' reflection text coupled with hierarchical visualization of analysis results by a focus group interview}

A focus group interview was conducted with three learners to further investigate learners' perception of the support from the computer-aided analysis of learners' reflection text coupled with hierarchical visualization of analysis results. The learners were asked to provide feedback on the questions related to the applicability of the tool such as "How does the hierarchical visualization tool influence my understanding of eLearning?"; on the questions related to the social context of the tool such as "Do you agree that the hierarchical visualization tool enhances the interaction between learners 
and teachers? If yes, how does it work out?". The qualitative feedback collected was summarized and analyzed systematically.

\section{Effectiveness of the pedagogical delivery of the e-Learning framework}

This section presents and discusses the results on the effectiveness of the pedagogical delivery of the proposed e-Learning framework to enhance learners' understanding of e-Learning.

\section{Learners' change in the understanding of e-Learning after the pedagogical delivery of the proposed e-Learning framework support}

Figure 3 shows the hierarchical visualization of the results of computer-aided analysis of learners' pre-teaching and post-teaching reflections on their understanding of eLearning. The number of matching keywords in the technology dimension (as denoted by the orange balls in Fig. 3) in the pre-teaching reflection and post-teaching reflection were 81 and 203 respectively, while the corresponding matching keywords in the pedagogy dimension were 69 and 221, respectively. These results showed that there was a significant increase in matching keywords from the pre-teaching reflection to the postteaching reflection. Learners were enabled to visualize the e-Learning framework interactively through the hierarchical visualization of pre-teaching reflection results after the first lesson. They referred to this visualization support for reflection in the process of the course activities of this study. For the technology dimension, learners produced a higher proportion of keywords in the "digital technology" component which covers items associated with the general use of digital technology in the pre-teaching reflection. This indicated that learners were not so familiar with technological issues specific for e-Learning practices in school education before taking the course. In the postteaching reflection, learners could use keywords across all the dimension-specific components in technology after the course. Learners had a noticeable increase in the use of keywords across all three dimension-specific components, with the number of matching keywords from 8 to 48 (i.e., six times) for the "digital ways of communication"
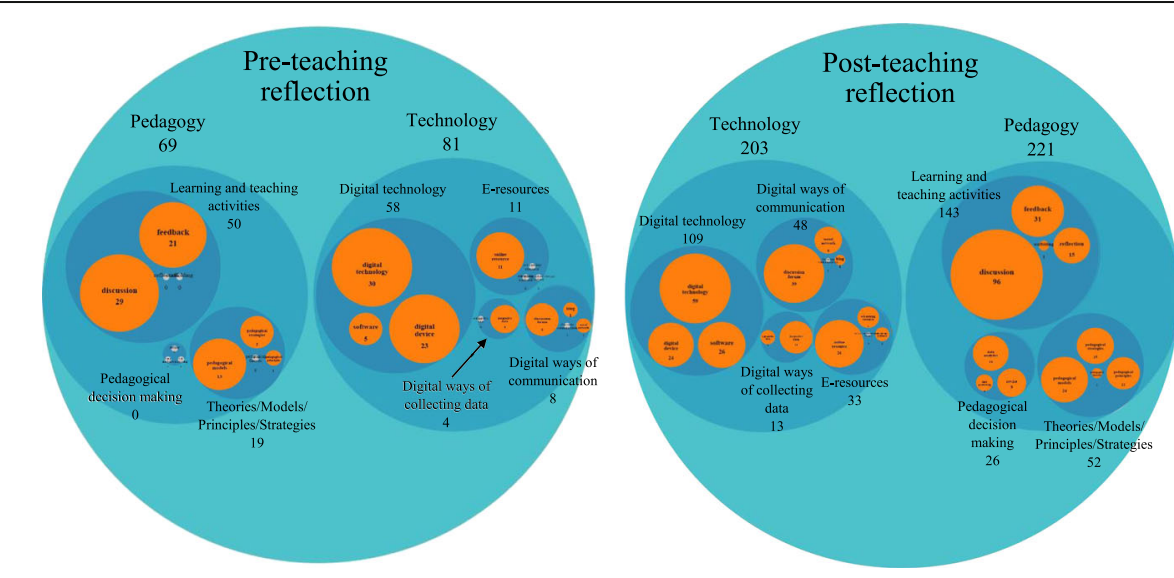

Fig. 3 Hierarchical visualization of the results on computer-aided analysis of learners' pre-teaching and post-teaching reflections on their understanding of e-Learning 
component; from 4 to 13 (i.e., three times) for the "digital ways of collecting data" component, and 11 to 33 (i.e., three times) for the "e-resources" component.

For the pedagogy dimension, learners had two evident improvements in using keywords across all the dimension-specific components after the course. First, all gray balls (denoting absent keywords) in the pre-teaching reflection changed to orange balls (denoting used keywords) in the post-teaching reflection. Second, learners also had a noticeable increase in using keywords across all the dimension-specific components in the post-teaching reflection, with the number of matching keywords from 50 to 143 (about five times) for the "learning and teaching activities" component; from 19 to 52 (about three times) for the "theories/models/principles/strategies" component and from 0 to 26 (start to use these keywords) for the "pedagogical decision-making" component. Table 4 shows examples of changes on learners' understanding of e-Learning. These two evident improvements show that the pedagogical delivery of the proposed eLearning framework can support learners to enhance their comprehensiveness of eLearning understanding, as this cohort of learners was able to mention all keyword sets of the pedagogy dimension in the post-teaching reflection. The visualization, therefore, can provide empirical data for the teacher to adjust pedagogical decision to address the learning needs of learners to achieve its planned goal.

Table 5 shows the statistical results of comparing the means of counting matching keywords of learners' pre-teaching and post-teaching reflections. The results showed that learners' understanding of e-Learning was enhanced in all components in the technology $((1)+(2)+(3))$ and pedagogy $((4)+(5)+(6))$ dimensions. It showed that learners had deepened their understanding of e-Learning in school education in both technological and pedagogical dimensions.

To further explain the changes of the counting of matching keywords of the eLearning framework in the pre-teaching and post-teaching reflections, the percentage change of counting of matching keywords and proportions of matching counts at all levels of the e-Learning framework in the pre-teaching and post-teaching reflections were analyzed and tabulated in Table 6.

The percentage changes in matching counts of the technology and pedagogy dimensions between the two reflections were $151 \%$ and $220 \%$, respectively. Before taking the course, learners paid more attention to the technology dimension in e-Learning. After taking the course, the proportion of matching counts of the technology dimension decreased from $54.0 \%$ to $47.9 \%$; while that of the pedagogy dimension increased from $46.0 \%$ to $52.1 \%$. These results provided evidences that the proposed e-Learning framework and its pedagogical delivery assisted learners to realize the importance of pedagogy in e-Learning in school education. There were four additional detailed observations.

Firstly, an observation from Table 6 was that learners in the post-teaching reflection had a significant reduction in the proportion of matching counts in the "digital technology" component decreased from $38.7 \%$ to $25.7 \%$, which is an additional technological component of the proposed e-Learning framework for recording common keywords associated with the general use of digital technology generated by learners. This result indicated that learners after taking the course recognized the use of e-resources, digital ways of communication, and digital ways of collecting data more relevant to eLearning. This was also evidenced by the increase in proportion of matching counts of 
Table 4 Examples of learners' pre-teaching and post-teaching reflections on their understanding of e-Learning

\begin{tabular}{|c|c|}
\hline Pre-teaching reflection & Post-teaching reflection \\
\hline \multicolumn{2}{|l|}{ Example 1: } \\
\hline $\begin{array}{l}\text { "By the use of electronic equipment and multimedia } \\
\text { in teaching such as interactive web pages, animations, } \\
\text { video, audio, etc., it is easier for students to learn, } \\
\text { grasp and consolidate abstract concepts and to } \\
\text { provide instant feedback to teachers. For students' } \\
\text { perspective, the learning process could occur at } \\
\text { anytime and anywhere." }\end{array}$ & $\begin{array}{l}\text { "The goal of e-Learning in a school could be set and } \\
\text { achieved using various electronic tools including elec- } \\
\text { tronic resources, electronic platforms of communica- } \\
\text { tion. The tools can also be applied to collect students' } \\
\text { learning data and outcomes, from which we could } \\
\text { understand the learning progress of students so that } \\
\text { the learning process is more efficient. In addition, } \\
\text { through the use of flipped classroom, student- } \\
\text { centered learning strategies can be realized by requir- } \\
\text { ing students to do preview at home in order to save } \\
\text { the time of direct instruction to cover basic know- } \\
\text { ledge. Consequently, the strategies facilitate group dis- } \\
\text { cussion in the lesson, the development of students' } \\
\text { higher-order thinking and the interaction between } \\
\text { teachers and students in the classroom." }\end{array}$ \\
\hline
\end{tabular}

Example 2:

"E-learning is the use of computing equipment to help student learning by improving learning

"E-Learning is a teaching method with the use of information technology. Student learning is assisted by motivation of students, their ability of self-learning and computer or telecommunications equipment. by strengthening teacher-students and peer interactions. Various learning activities become possible so that it is more interactive in lecturing and students' learning activities can be diversified. The learning materials and locations are not limited to textbooks or classrooms respectively. Also, the forms of assessment/ homework can be diversified so that they are no longer limited to text. For examples, audio, pictures, video can be used. Moreover, instant statistics from students' answers can be drawn so that teachers can provide feedback to students in the lesson quickly."

Therefore, student learning is not restricted by time and location so that ability of self-learning is promoted. After the implementation of e-Learning, teaching resources are diversified including digital multimedia and online resources. The resources would enhance learning motivation of students and help students understanding abstract concepts so that their ability of inquiry can be enhanced. On the other hand, the teaching resources also provide learning support to cater for the individual learning needs of students. The teaching contents could also be digitalized. This digital way of communication enhances not only instant sharing and feedback in the classroom and but also online interaction through some learning platforms after school so that teacher-student and peer interactions could be strengthened. The communication and collaboration skills of students could be enhanced. Besides, teachers can use IT equipment to assess instant statistics based on students' answers, to perform data analysis and to provide feedback quickly during the lesson. Since most of the learning data could be recorded, stakeholders including teachers, students and parents could check the learning process of students through e-portfolio, from which teachers are allowed to reflect and enhance their pedagogical skills."

keywords in the components of "e-resources," "digital ways of communication," and "digital ways of collecting data" from $7.3 \%$ to $7.8 \%, 5.3 \%$ to $11.3 \%$, and $2.7 \%$ to $3.1 \%$, respectively.

Secondly, the results of comparing the proportion of matching counts of categories in the component of "digital ways of communication" in pre-teaching and postteaching reflections indicated that the categories of "discussion forum" and "social network" increased from $4.0 \%$ to $9.2 \%$ and $0.7 \%$ to $1.9 \%$, respectively, which contributed significantly to the increase in the number of matching keywords of the "digital ways of communication" component. These results reflected that learners considered "digital ways of communication" is important in e-Learning after attending the course. Participants also started to realize the importance of "digital ways of collecting data" for 
Table 5 Comparison of means of counting matching keywords from the results on computeraided analysis of learners' pre-teaching and post-teaching reflections on their understanding of eLearning

\begin{tabular}{|c|c|c|c|c|c|}
\hline \multirow[t]{2}{*}{$\begin{array}{l}\text { Component (1) to (6)/Dimension (7) } \\
\text { and (8) }\end{array}$} & \multicolumn{2}{|c|}{$\begin{array}{l}\text { Counting matching } \\
\text { keywords of pre-teaching } \\
\text { reflection on e-Learning } \\
\text { understanding }\end{array}$} & \multicolumn{2}{|c|}{$\begin{array}{l}\text { Counting matching } \\
\text { keywords of post-teaching } \\
\text { reflection on e-Learning } \\
\text { understanding }\end{array}$} & \multirow[t]{2}{*}{$t$-test } \\
\hline & Mean & S.D. & Mean & S.D. & \\
\hline (1) E-resources & 0.344 & 0.653 & 1.031 & 1.402 & $2.502^{*}$ \\
\hline (2) Digital ways of communication & 0.250 & 0.440 & 1.500 & 1.760 & $3.937^{* *}$ \\
\hline (3) Digital ways of collecting data & 0.125 & 0.336 & 0.406 & 0.665 & $2.738^{*}$ \\
\hline (4) Theories/models/principles/strategies & 0.594 & 0.560 & 1.625 & 2.225 & $2.560^{*}$ \\
\hline (5) Learning and teaching activities & 1.563 & 1.435 & 4.469 & 4.064 & $4.495^{* *}$ \\
\hline (6) Pedagogical decision-making/support & 0.000 & 0.000 & 0.813 & 1.176 & $3.908^{* *}$ \\
\hline (7) Technology: (1) + (2) + (3) & 0.719 & 0.958 & 2.938 & 3.192 & $3.960^{* *}$ \\
\hline (8) Pedagogy: (4) + (5) + (6) & 2.156 & 1.568 & 6.906 & 6.291 & $4.557^{* *}$ \\
\hline (9) Total: (7) + (8) & 2.875 & 2.152 & 9.844 & 9.042 & $4.584^{* *}$ \\
\hline
\end{tabular}

formative assessment as evidenced by the increase in matching keywords from 4 to 11 that is an increase of $175 \%$.

Thirdly, the results of comparing the proportion of matching counts of categories in the component of "learning and teaching activities" in pre-teaching and post-teaching reflections indicated that the categories of "reflection" and "discussion" increased from $0 \%$ to $3.5 \%$ and $19.3 \%$ to $22.6 \%$ respectively, which contributed significantly to the increase in the number of matching keywords of the "learning and teaching activities" component. It can be concluded that learners considered "reflection" and "discussion" as important learning and teaching activities in e-Learning in school education.

Table 6 The percentage change of counting of matching keywords and proportions of matching counts at all levels of the e-Learning framework in the pre-teaching and post-teaching reflections

\begin{tabular}{|c|c|c|c|c|c|}
\hline \multirow{2}{*}{$\begin{array}{l}\text { Proposed e- } \\
\text { Learning framework }\end{array}$} & \multicolumn{3}{|c|}{ Counting of matching keywords } & \multicolumn{2}{|c|}{ Proportion of matching counts } \\
\hline & $\begin{array}{l}\text { Pre-teaching } \\
\text { reflection }\end{array}$ & $\begin{array}{l}\text { Post-teaching } \\
\text { reflection }\end{array}$ & $\begin{array}{l}\text { Percentage } \\
\text { change }\end{array}$ & $\begin{array}{l}\text { Within Pre- } \\
\text { teaching } \\
\text { reflection }\end{array}$ & $\begin{array}{l}\text { Within Post- } \\
\text { teaching } \\
\text { reflection }\end{array}$ \\
\hline $\begin{array}{l}\text { Total: technology and } \\
\text { pedagogy }\end{array}$ & 150 & 424 & $183 \%$ & $100 \%$ & $100 \%$ \\
\hline Technology & 81 & 203 & $151 \%$ & $54.0 \%$ & $47.9 \%$ \\
\hline E-resources & 11 & 33 & $200 \%$ & $7.3 \%$ & $7.8 \%$ \\
\hline $\begin{array}{l}\text { Digital ways of } \\
\text { communication }\end{array}$ & 8 & 48 & $500 \%$ & $5.3 \%$ & $11.3 \%$ \\
\hline $\begin{array}{l}\text { Digital ways of } \\
\text { collecting data }\end{array}$ & 4 & 13 & $225 \%$ & $2.7 \%$ & $3.1 \%$ \\
\hline Digital technology & 58 & 109 & $88 \%$ & $38.7 \%$ & $25.7 \%$ \\
\hline Pedagogy & 69 & 221 & $220 \%$ & $46.0 \%$ & $52.1 \%$ \\
\hline $\begin{array}{l}\text { Theories/models/ } \\
\text { principles/strategies }\end{array}$ & 19 & 52 & $174 \%$ & $12.7 \%$ & $12.3 \%$ \\
\hline $\begin{array}{l}\text { Learning and } \\
\text { teaching activities }\end{array}$ & 50 & 143 & $186 \%$ & $33.3 \%$ & $33.7 \%$ \\
\hline $\begin{array}{l}\text { Pedagogical decision- } \\
\text { making/support }\end{array}$ & 0 & 26 & - & $0.0 \%$ & $6.1 \%$ \\
\hline
\end{tabular}


Fourthly, the results of comparing the proportion of matching counts of categories in the component of "pedagogical decision-making/support" in pre-teaching and postteaching reflections indicated that the categories of "learning data" and "revise/modify" increased from $0 \%$ to $3.3 \%$ and $0 \%$ to $2.1 \%$ respectively, which contributed significantly to the increase in the number of matching keywords of the "pedagogical decisionmaking/support" component.

Learners' perception of the helpfulness of the support from the computer-aided analysis of learners' reflection text coupled with hierarchical visualization of analysis results on promoting their e-Learning understanding

Table 7 showed survey results of learners' perception of the e-Learning framework with the support from the computer-aided analysis of learners' reflection text coupled with hierarchical visualization of analysis results. The survey results showed that learners in general positively perceived the e-Learning framework with the support from computer-aided analysis and hierarchical visualization for fostering their understanding of e-Learning, with all item ratings in the range of 4.065 to 4.452 (with 5 as maximum). The learners agreed most the impact of the hierarchical visualization tool for providing them with useful information from all participants in the teacher development course, which stimulated their individual understanding of e-Learning. In addition to enabling them to develop intellectual ideas of e-Learning, the learners also indicated that the functions of the hierarchical visualization support can help them link personal learning intentions and expectations by providing an opportunity for them to reflect on their individual understanding of e-Learning and arousing their attention to the understanding of e-Learning.

Table 8 showed focus group interview results of learners' perception of the eLearning framework with the support from computer-aided analysis and hierarchical visualization. The interview results showed learners' positive perception of the support from computer-aided analysis and hierarchical visualization. They indicated that the eLearning framework presented in hierarchical visualization was effective in enhancing their understanding of e-Learning. The hierarchical visualization of the pre-teaching reflection results allowed them to reflect on their individual understanding as well as

Table 7 Survey results of learners' perception of the e-Learning framework with the support from computer-aided analysis and hierarchical visualization

\begin{tabular}{lcc}
\hline Item & Mean & S.D. \\
\hline Provides useful information from all participants for my understanding of e-Learning & 4.452 & 0.498 \\
Enables me to have a better understanding of e-Learning & 4.419 & 0.493 \\
Empowers me to explore the meaning of e-Learning with this tool & 4.387 & 0.549 \\
Provides an opportunity for me to reflect my understanding of e-Learning & 4.323 & 4.458 \\
Arouses my attention to the understanding of e-Learning & 4.258 & 0.438 \\
Enables me to interact more with my lecturer & 4.226 & 0.438 \\
Enables me to have more interaction with my learning peers & 4.161 & 0.489 \\
Enlightens me to have one more study method and skill & 4.097 & 0.530 \\
Empowers my control over learning & 4.065 & 0.669 \\
Increases my learning motivation & 447 \\
\hline
\end{tabular}

Note: 5 = Strongly agree, 4 = Agree, 3 = Neutral, 2 = Disagree, $1=$ Strongly disagree 
Table 8 Focus group interview results of learners' perception of the e-Learning framework with the support of computer-aided analysis and hierarchical visualization

\begin{tabular}{|c|c|}
\hline & Major feedback from learners' focus group interview \\
\hline \multirow[t]{3}{*}{$\begin{array}{l}\text { Changes in the understanding of } \\
\text { e-Learning }\end{array}$} & $\begin{array}{l}\text { The visualization showed a concrete and easy-to-read framework of e- } \\
\text { Learning for learners to enhance their understanding of e-Learning in } \\
\text { school education. }\end{array}$ \\
\hline & $\begin{array}{l}\text { By viewing the hierarchical visualization of the pre-teaching reflection, } \\
\text { learners could reflect their individual understanding of e-Learning in the } \\
\text { teacher development course. }\end{array}$ \\
\hline & $\begin{array}{l}\text { The visualization allowed learners to compare their individual reflection } \\
\text { with their classmates' reflections for understanding more about e- } \\
\text { Learning. }\end{array}$ \\
\hline \multirow[t]{2}{*}{$\begin{array}{l}\text { Suggestions for the hierarchical } \\
\text { visualization support }\end{array}$} & $\begin{array}{l}\text { The learners suggested that an option button could be designed to add } \\
\text { pre-teaching reflection for their use in writing their post-teaching } \\
\text { reflection. }\end{array}$ \\
\hline & $\begin{array}{l}\text { The learners suggested that a more convenient way of showing keywords } \\
\text { should be developed for displaying keyword names across different layers. }\end{array}$ \\
\hline
\end{tabular}

discussion among peer of e-Learning early at the beginning of the course. The hierarchical visualization support also allowed them to deepen their learning by comparing their individual understanding with the whole-class understanding of e-Learning. The learners also suggested ways to improve the design of the interface of the hierarchical visualization support.

\section{Conclusion and future works}

The study proposed an e-Learning framework consisting of the "technology" and "pedagogy" dimensions; and used the approach of computer-aided analysis of learners' reflection text coupled with hierarchical visualization of analysis results to support the delivery and evaluation of learners' learning in a cohort of seven-lesson teacher development course on "E-Learning in Primary Schools", which provided reflection opportunities and experiences to enable learners to understand the need of theoretical guidance in designing e-Learning activities for achieving the educational goal. Learners' reflection text on e-Learning before and after the teaching of the course indicated that learners enhanced their understanding of e-Learning through the counting of matching keywords of the framework. The computer-aided analysis of the reflections showed that learners mentioned less general digital technology terms such as using a computer for learning and realized a more in-depth understanding of the role of technology in eLearning. They realized that e-Learning was not just the use of e-resources for learning but also the use of digital ways of communication like the use of discussion forum and social network for learning. They also started to realize the importance of data collection from e-Learning platforms in e-Learning. The computer-aided analysis of the reflections also indicated that learners understood more the importance of pedagogy in e-Learning. Learners particularly showed more consideration on reflection and discussion opportunities in learning and teaching activities in e-Learning and started realizing more the possibility of pedagogical decision-making based on data collected from online learning.

As found by the survey and focus group interview, learners positively perceived the hierarchical visualization support for interaction with the proposed e-Learning framework for a better understanding of e-Learning. They treasured the opportunities in 
comparing their own individual understanding with the whole-class understanding using the proposed e-Learning framework. They valued the opportunities provided for peer discussion on the concrete details of e-Learning activities supported by the proposed framework. The peer discussion provided opportunities for individual reflection on directions for personal expectations of e-Learning development.

This study pioneers the contributions to research literature on the use of computeraided analysis for an accurate and efficient evaluation of learning progress and outcome among in-service teachers in teacher development courses on e-Learning. This study made an evident contribution that the proposed e-Learning framework and its pedagogical delivery are effective and well-received for preparing in-service teachers in school education. It encourages teachers to plan and design pedagogically desirable learning and teaching activities as well as to make evidence-based pedagogical decisions in promoting e-Learning in school context.

There are two limitations of this research. First, the e-Learning framework is at the proposed stage. The keywords in each dimension need to be further refined. Second, this study only conducted the evaluation in one teacher development course on eLearning. There are three directions for the further research of this study. First, the eLearning framework should be practiced in more cohorts of learners to further refine its keyword and add more validation of its effectiveness for evaluation. Second, the pedagogical delivery of such framework can be extended to enable learners to compare their own individual results with the whole-class results on the computer-aided analysis of pre-teaching as well as post-teaching reflections, and in turn facilitating learners to deepen their reflection. Third, to enable teachers in teacher development to use the result of computer-aided analysis to make pedagogical decisions to improve learners' understanding of the e-Learning framework, teachers might add one more reflection between the pre-teaching and post-teaching reflection so that teachers can adjust their teaching using result from this reflection.

Acknowledgements

The author would like to acknowledge the funding support from the Hong Kong UGC (University Grants Committee) TDG (Teaching Development Grant) (Ref: HKIED7/T\&L/12-15).

Author's contributions

The author is responsible for the whole manuscript. The author read and approved the final manuscript.

Author's information

Siu-Cheung Kong is Professor of the Department of Mathematics and Information Technology; and Director of Centre for Learning, Teaching and Technology, the Education University of Hong Kong. His research interests include pedagogy in the digital classroom and online learning, policy on technology-transformed education and professional development of teachers for learner-centered learning, and computational thinking education.

Funding

Not applicable

Availability of data and materials

Not applicable

\section{Declarations}


Received: 9 February 2021 Accepted: 2 August 2021

Published online: 06 September 2021

\section{References}

Acar, O. A., \& Tuncdogan, A. (2019). Using the inquiry-based learning approach to enhance student innovativeness: a conceptual model. Teaching in Higher Education, 24(7), 895-909. https://doi.org/10.1080/13562517.2018.1516636.

Adekola, J., \& Dale, V. (2017). Development of an institutional framework to guide transitions into enhanced blended learning in higher education. Research in Learning Technology, 25, 16. https://doi.org/10.25304/rlt.v25.1973.

Albion, P., Tondeur, J., Forkosh-Baruch, A., \& Peeraer, J. (2015). Teachers' professional development for ICT integration: Towards a reciprocal relationship between research and practice. Education and Information Technologies, 20(4), 655-673. https://doi.org/10.1007/s10639-015-9401-9.

Aparicio, M., Bacao, F., \& Oliveira, T. (2016). An e-Learning theoretical framework. Educational Technology \& Society, 19(1), 292307.

Bashan, B., Holsblat, R., \& Mark, B. (2017). Reflective journals as a research tool: The case of student teachers' development of teamwork. Cogent Education, 4(1) 1374234, 15.

Bikakis, N., Papastefanatos, G., Skourla, M., \& Sellis, T. (2017). A hierarchical aggregation framework for efficient multilevel visual exploration and analysis. Semantic Web, 8(1), 139-179.

Blair, E., Maharaj, C., \& Primus, S. (2016). Performance and perception in the flipped classroom. Education and Information Technologies, 21(6), 1465-1482. https://doi.org/10.1007/s10639-015-9393-5.

Blau, I., \& Shamir-Inbal, T. (2017). Re-designed flipped learning model in an academic course: The role of co-creation and coregulation. Computers in Education, 115, 69-81. https://doi.org/10.1016/j.compedu.2017.07.014.

Blundell, C., Lee, K.-T., \& Nykvist, S. (2020). Moving beyond enhancing pedagogies with digital technologies: Frames of reference, habits of mind and transformative learning. Journal of Research on Technology in Education, 52(2), $178-196$. https://doi.org/10.1080/15391523.2020.1726235.

Chou, T.-L., Wu, J.-J., \& Tsai, C.-C. (2019). Research trends and features of critical thinking studies in e-learning environments: A review. Journal of Educational Computing Research, 57(4), 1038-1077. https://doi.org/10.1177/0735633118774350.

Damnik, G., Proske, A., \& Körndle, H. (2017). Designing a constructive learning activity with interactive elements: The effects of perspective-shifting and the quality of source material. Interactive Learning Environments, 25(5), 634-649. https://doi.org/1 $0.1080 / 10494820.2016 .1172239$

DiCerbo, K. (2020). Assessment for learning with diverse learners in a digital world. Educational Measurement: Issues and Practice, 39(3), 90-93. https://doi.org/10.1111/emip.12374.

Egberink, I. J. L., Meijer, R. R., \& Tendeiro, J. N. (2015). Investigating measurement invariance in computer-based personality testing: The impact of using anchor items on effect size indices. Educational and Psychological Measurement, 75(1), 126145. https://doi.org/10.1177/0013164414520965.

Eid, M. I. M., \& Al-Jabri, I. M. (2016). Social networking, knowledge sharing, and student learning: The case of university students. Computers in Education, 99, 14-27. https://doi.org/10.1016/j.compedu.2016.04.007.

Elmqvist, N., \& Fekete, J.-D. (2010). Hierarchical aggregation for information visualization: Overview, techniques, and design guidelines. IEEE Transactions on Visualization and Computer Graphics, 16(3), 439-454. https://doi.org/10.1109/TVCG.2009.84.

Fahrenbach, F., Revoredo, K., \& Santoro, F. M. (2019). Valuing prior learning: Designing an ICT artifact to assess professional competences through text mining. European Journal of Training and Development, 44(2/3), 209-235. https://doi.org/10.11 08/EJTD-05-2019-0070.

Greenhow, C., \& Lewin, C. (2016). Social media and education: Reconceptualizing the boundaries of formal and informal learning. Learning, Media and Technology, 41(1), 6-30. https://doi.org/10.1080/17439884.2015.1064954.

Jones, M., \& Dexter, S. (2018). Teacher perspectives on technology integration professional development: Formal, informal, and independent learning activities. Journal of Educational Multimedia and Hypermedia, 27(1), 83-102.

Koh, J. H. L., Chai, C. S., \& Lim, W. Y. (2017). Teacher professional development for TPACK-21CL: Effects on teacher ICT integration and student outcomes. Journal of Educational Computing Research, 55(2), 172-196. https://doi.org/10.1177/073 5633116656848

Kong, S.C. (2014). Developing information literacy and critical thinking skills through domain knowledge learning in digital classrooms: An experience of practicing flipped classroom strategy. Computers and Education, 78, 160-173.

Kong, S.C. (2015). An experience of a three-year study on the development of critical thinking skills in flipped secondary classrooms with pedagogical and technological support. Computers and Education, 89, 16-31.

Kong, S.C., Chan, T.-W., Griffin, P., Hoppe, U., Huang, R., Kinshuk, Looi, C.K., Milrad, M., Norris, C., Nussbaum, M., Sharples, M., So, W.M.W., Soloway, E., \& Yu, S. (2014). E-learning in school education in the coming 10 years for developing 21 st century skills: Critical research issues and policy implications. Educational Technology and Society, 17(1), 70-78.

Kong, S.C., \& Song, Y. (2014). The impact of a principle-based pedagogical design on inquiry-based learning in a seamless learning environment in Hong Kong. Educational Technology and Society, 17(2), 127-141.

Kong, S. C., \& Song, Y. (2015). An experience of personalized learning hub initiative embedding BYOD for reflective engagement in higher education. Computers \& Education, 88, 227-240.

Krasnova, G. A., Nuhuly, A., \& Teslenko, V. A. (2017). E-learning: Current state, trends and future prospects. RUDN Journal of Informatization in Education, 14(3), 371-377. https://doi.org/10.22363/2312-8631-2017-14-3-371-377.

Leow, F.-T., Neo, M., \& Hew, S. H. (2016). Investigating the key attributes to enhance students' learning experience in $21 \mathrm{st}$ century class environment. Electronic Journal of e-Learning, 14(4), 244-256.

Liao, Y.-C., Ottenbreit-Leftwich, A., Karlin, M., Glazewski, K., \& Brush, T. (2017). Supporting change in teacher practice: Examining shifts of teachers' professional development preferences and needs for technology integration. Contemporary Issues in Technology and Teacher Education, 17(4), 522-548.

Littlejohn, A., Hood, N., Milligan, C., \& Mustain, P. (2016). Learning in MOOCs: Motivations and self-regulated learning in MOOCs. The Internet and Higher Education, 29, 40-48. https://doi.org/10.1016/j.iheduc.2015.12.003.

McConnell, D. (2018). E-learning in Chinese higher education: The view from inside. Higher Education, 75(6), $1031-1045$. https://doi.org/10.1007/s10734-017-0183-4. 
Mchaney, R., Reiter, L., \& Reychav, I. (2018). Immersive simulation in constructivist-based classroom e-learning. International Journal on E-Learning, 17(1), 29-64.

McKenna, K., Pouska, B., Moraes, M. C., \& Folkestad, J. E. (2019). Visual-form learning analytics: A tool for critical reflection and feedback. Contemporary Educational Technology, 10(3), 214-228.

McKnight, K., O'Malley, K., Ruzic, R., Horsley, M. K., Franey, J. J., \& Bassett, K. (2016). Teaching in a digital age: How educators use technology to improve student learning. Journal of Research on Technology in Education, 48(3), 194-211. https://doi org/10.1080/15391523.2016.1175856.

McLean, N., \& Price, L. (2019). A longitudinal study of the impact of reflective coursework writing on teacher development courses: A 'legacy effect' of iterative writing tasks. Higher Education, 77(5), 949-962. https://doi.org/10.1007/s10734-018$0312-8$.

Noroozi, O., Alikhani, I., Järvelä, S., Kirschner, P. A., Juuso, I., \& Seppänen, T. (2019). Multimodal data to design visual learning analytics for understanding regulation of learning. Computers in Human Behavior, 100, 298-304. https://doi.org/10.1016/j. chb.2018.12.019.

Oktavia, T., Prabowo, H., \& Meyliana, H. (2016). The general components of e-learning framework for higher institution: A systematic literature review. Journal of Telecommunication, Electronic and Computer Engineering, 8(3), 55-59.

Pereira, I. S. P., Parente, M. C. C., \& Silva, C. V. (2016). Guided portfolio writing as a scaffold for reflective learning in in-service contexts: A case study. Teacher Development, 20(5), 614-630. https://doi.org/10.1080/13664530.2016.1185029.

Rodríguez, A. I., Riaza, B. G., \& Gómez, M. C. S. (2017). Collaborative learning and mobile devices: An educational experience in Primary Education. Computers in Human Behavior, 72, 664-677. https://doi.org/10.1016/j.chb.2016.07.019.

Tondeur, J., Forkosh-Baruch, A., Prestridge, S., Albion, P., \& Edirisinghe, S. (2016). Responding to challenges in teacher professional development for ICT integration in education. Educational Technology \& Society, 19(3), 110-120.

Varier, D., Dumke, E. K., Abrams, L. M., Conklin, S. B., Barnes, J. S., \& Hoover, N. R. (2017). Potential of one-to-one technologies in the classroom: Teachers and students weigh in. Educational Technology Research and Development, 65(4), 967-992. https://doi.org/10.1007/s11423-017-9509-2.

Vieira, C., Parsons, P., \& Byrd, V. (2018). Visual learning analytics of educational data: A systematic literature review and research agenda. Computers in Education, 122, 119-135. https://doi.org/10.1016/j.compedu.2018.03.018.

Walt, P. S. D., \& Barker, N. (2020). Pedagogical intersectionality: Exploring content, technology, and student-centered learning through a problem based/project based approach. Educational Media International, 57(1), 29-46. https://doi.org/10.1080/ 09523987.2020.1744847.

Yen, M. H., Chen, S., Wang, C. Y., Chen, H. L., Hsu, Y. S., \& Liu, T. C. (2018). A framework for self-regulated digital learning (SRDL). Journal of Computer Assisted Learning, 34(5), 580-589. https://doi.org/10.1111/jcal.12264.

Yurtseven Avci, Z., O'Dwyer, L. M., \& Lawson, J. (2020). Designing effective professional development for technology integration in schools. Journal of Computer Assisted Learning, 36(2), 160-177. https://doi.org/10.1111/jcal.12394.

Zanjani, N., Edwards, S. L., Nykvist, S., \& Geva, S. (2017). The important elements of LMS design that affect user engagement with e-learning tools within LMSs in the higher education sector. Australasian Journal of Educational Technology, 33(1), $19-31$

\section{Publisher's Note}

Springer Nature remains neutral with regard to jurisdictional claims in published maps and institutional affiliations.

\section{Submit your manuscript to a SpringerOpen ${ }^{\circ}$ journal and benefit from:}

- Convenient online submission

- Rigorous peer review

- Open access: articles freely available online

- High visibility within the field

- Retaining the copyright to your article

Submit your next manuscript at $\boldsymbol{s p r i n g e r o p e n . c o m ~}$ 